\title{
Mercury fractionation in gypsum using temperature desorption and mass spectrometric detection
}

\author{
Mass spectrometric approach to mercury fractionation in FGD gypsum
}

https://doi.org/10.1515/chem-2018-0046

received December 6, 2017; accepted March 8, 2018.

\begin{abstract}
A quadrupole mass spectrometer was used to study the thermal release of mercury from wet flue gas desulphurization (WFGD) gypsum using temperatureprogrammed desorption/decomposition (TPD). The inability in direct detection of low concentrations of mercury halogenides in gypsum by mass spectrometry is discussed in detail. The hydrolysis of $\mathrm{HgCl}_{2}$ vapours under specific experimental conditions in the mass spectrometer was considered theoretically and proved experimentally. The mercury concentration in different gypsum fractions varies from $0.22 \mathrm{mg} \mathrm{kg}^{-1}$ (3.27-148 $\mu \mathrm{m}$, coarse particles) to $20.6 \mathrm{mg} \mathrm{kg}^{-1}(0.41-88.0 \mu \mathrm{m}$, fine particles). All samples had a similar, symmetrical, single-peak (peak maximum $253-266^{\circ} \mathrm{C}$ ) in the TPD spectra. In the present study, the use of 'wet' methods for preparing mercury compounds is introduced in addition to the mercury standards prepared using the 'dry' method, as commonly found in TPD. The study showed that selected metals, such as Fe enriched in gypsum samples, significantly influence the shape and the maximum temperature of the Hg TPD curves and that during the mercury compound preparation and the TPD process, $\mathrm{Hg}$ species undergo transformations that prevent the identification of their original identity.
\end{abstract}

Keywords: Mass spectrometry; Mercury; Temperatureprogrammed desorption; WFGD gypsum; Particle size fractions.

*Corresponding author: Milena Horvat, Department of Environmental Sciences, Jožef Stefan Institute, Jamova cesta 39, 1000 Ljubljana, Slovenia; Jožef Stefan International Postgraduate School, Jamova cesta 39, 1000 Ljubljana, Slovenia, E-mail: milena.horvat@ijs.si Majda Pavlin, Arkadij Popović, Radojko Jaćimović: Department of Environmental Sciences, Jožef Stefan Institute, Jamova cesta 39, 1000 Ljubljana, Slovenia

Majda Pavlin, Radojko Jaćimović: Jožef Stefan International Postgraduate School, Jamova cesta 39, 1000 Ljubljana, Slovenia

\section{Introduction}

In the last decade, great efforts have been made to understand the chemistry of mercury and mercury compounds in the wet flue gas desulphurization system (WFGD). During coal combustion, limestone and flue gas together with fine fly ash that is not retained by electrostatic precipitators (ESP) are important sources of chemical elements in the WFGD system [1-4]. In WFGD slurry, mercury is involved in different oxidation/reduction and precipitating reactions [5-9]. Adsorption could also be an important process and depends on the ligands and minerals (particles) present [10,11]. Different Hg species such as $\mathrm{HgCl}_{2}, \mathrm{Hg}_{2} \mathrm{Cl}_{2}, \mathrm{HgO}, \mathrm{HgS}$ and $\mathrm{HgSO}_{4}$ have been identified in WFGD gypsum [1,12-19]. Several studies also reported higher concentrations of $\mathrm{Hg}$ in samples enriched with $\mathrm{Fe}(\mathrm{Al})[2-4,20-22]$.

The common approach for determining mercury species in solid samples such as gypsum is to use temperature-programmed desorption/decomposition (TPD) with an atomic absorption spectrometer (AAS) as the detector [23-26], whereas a mass spectrometer (MS) is rarely applied [27-30]. TPD method is basically a transpiration method [31] where the stability of a mercury compound refers to the temperature at which the $\mathrm{Hg}$ signal reaches its maximum peak temperature. This approach is based on the mathematical treatment (peak fit) of the TPD spectra (thermograms) and a comparison of the spectra of different mercury standards to that of actual samples. There remain, however, several limitations of the TPD method including the following:

a) The dry mixing of pure mercury compounds with the substrate (e.g. $\left.\mathrm{CaSO}_{4} \cdot 2 \mathrm{H}_{2} \mathrm{O}\right)$ is typically used to prepare standards, but this means that mercury compounds are adsorbed on the surface of the crystals. In WFGD gypsum, Hg compounds can be present within the crystal bulk, since these compounds are already present in solution. Additionally, the gypsum slurry 
contains other types of particulate matters with varying adsorption affinities (particles coming into the system via fly ash and through the addition of limestone, such as Fe oxides). Therfore, neither the same maximum peak temperature nor spectra are obtained in both cases.

b) When using conventional AAS or AFS as a detector, sample matrix and its particle size distribution, the heating ramp, type of the carrier gas, carrier gas flow rate, sample weight, sampling procedure and analysis (sampling) time affect the release of $\mathrm{Hg}$, which shift the desorption/decomposition peak towards either lower or higher temperatures and change the peak intensity $[1,13,15,16,25,26,32,33]$. All these factors are responsible for the discrepancies observed in the measurement of $\mathrm{Hg}$ species among various laboratories, and unfortunately, as yet, no standardized method has been established for determining $\mathrm{Hg}$ speciation/fractionation in solid samples.

In previous studies, we examined the effect of particle size on mercury accumulation in WFGD gypsum from the lignite burning Šoštanj thermal power plant (Šoštanj TPP, Slovenia) and identified possible Hg-species present in the fine fraction of the gypsum [13,34]. Because the sensitivity of TPD method with AAS detection was not sufficient to detect low concentrations of $\mathrm{Hg}$ in coarse solid gypsum fractions, we turned to mass spectrometry. We hypothesise that high sensitivity and the ability to measure other volatile species and their fractions would allow us to identify the $\mathrm{Hg}$ species present in the gypsum samples. Literature data suggest that, in the gypsum, $\mathrm{HgCl}_{2}$ and $\mathrm{HgS}$ are the main compounds present. Since $\mathrm{Fe}$ is enriched in the fine gypsum particle fraction compared to the coarser fraction (Šoštanj TPP), we also investigate the influence of $\mathrm{Fe}$ on the desorption/decomposition of different $\mathrm{Hg}$-species during desorption process. We also make a comparison of wet and dry methods for preparing "mercury standards" using different substrates.

\section{Experimental section}

Three different samples of gypsum slurry were collected from a WFGD scrubber (block 6) at the Šoštanj thermal power plant TPP, Slovenia. The plant is equipped with a selective catalytic reduction (SCR) DeNOx system for controlling nitrogen oxide emissions $\left(\mathrm{NO}_{\mathrm{x}}\right)$, ESP to eliminate particles and WFGD units for removing $\mathrm{SO}_{2}$.

\subsection{Sampling and sample preparation}

Three different gypsum slurry samples were collected simultaneously at different sampling points: one from the main scrubber (the absorber), and two from the hydrocyclone. The original gypsum slurry (ORIG) was a sample of the WFGD slurry taken from the absorber. Within the hydrocyclone, the gypsum slurry was separated into disposal gypsum (DISP), which removed the hydrocyclone, further processed for disposal and re-circulated slurry water (RECY), which contained the finest particles and was pumped back into the main scrubber.

In the laboratory, each sample was homogenised (by shaking), transferred to a centrifuge tube $(50 \mathrm{ml})$ and left to settle under gravity for 48 hours until two distinct layers were formed. Although the bottom layer represented the coarse fraction (CF) consolidated within minutes, it took at least 48 hours for the upper layer, i.e., the fine fraction (FF) to separate entirely from the water phase. The water was then decanted and the remaining brownish slurry (FF) was transferred into a clean centrifuge tube and centrifuged at $2500 \mathrm{rpm}$ for 30 minutes. After removing the water, the residual paste was transferred into four Teflon containers where it was left to dry. This resulted in four separate fractions: ORIG-FF, ORIG-CF, DISP-FF and DISP-CF. The RECY sample contained the finest particles, and only one fraction was formed. A whole (bulk) gypsum sample (ORIG) was also prepared.

\subsection{Sample characterization}

Particle size distributions were determined in each of the five fractions, using a Microtrac PSA FRA 9200 based on the Fraunhofer laser diffraction method. Each fraction was dried to a constant weight at $38^{\circ} \mathrm{C}$ in an electric dryer (MEMMERT UFE 500). After drying, each sample was homogenised by grinding in an agate pestle and mortar.

Multi-elemental analyses were performed on all five fractions (ORIG-FF, ORIG-CF, DISP-FF, DISP-CF and RECY). The concentrations of major, minor and trace elements were obtained using the $\mathrm{k}_{0}$-standardisation neutron activation analysis method ( $\mathrm{k}_{0}$-INAA). Detail description of the method is provided in the supplementary material (Text S1).

Structural imaging and chemical characterisation of the solid particles (fine and coarse fractions) were obtained by field-emission-gun scanning electron microscopy (FEGSEM) performed on a JEOL JSM-7600F SEM equipped with an energy dispersive spectrometer (EDS) INCA Oxford 350. The samples were fixed with carbon tape and coated with amorphous carbon by evaporation (Balzers CED) and 
then morphologically and chemically characterised using the SEM. Images were obtained at a $5 \mathrm{kV}$ accelerating voltage and $0.1 \mathrm{pA}$ electron beam current, measured with an inside column Faraday cup.

Thermogravimetric (TG) and differential thermal analysis (DTA) were conducted on a Netzsch STA 409 C/CD coupled to a Balzers Quadstar 422 quadrupole mass spectrometer. Approximately $50 \mathrm{mg}$ of the reagent mixture was heated in a Pt/Rh crucible. Thermal changes were recorded under a dynamic flow of synthetic air of $100 \mathrm{~mL} \mathrm{~min}{ }^{-1}$. Measurements were made from $25^{\circ} \mathrm{C}$ to $550^{\circ} \mathrm{C}$ at a rate of $10^{\circ} \mathrm{C} \mathrm{min}^{-1}$.

Temperature programmed desorption process using mass spectrometry: In the present work, two different MS instruments were used. In the initial stage, a single focusing magnet mass spectrometer equipped with a Nier-type ion source (NT-MS) was used. The spectrometer had previously been employed for making Knudsen effusion experiments (KEMS method) [35,36], but in the present study, a quartz tube $(10 \mathrm{~cm} \times 3 \mathrm{~mm}$ I.D. $)$ closed at one end was used instead of Knudsen cell. The solid sample (1-10 mg) was placed at one end of the tube and the open end securely fitted into the ionization volume of the Nier ion source. The sample end of the introduction tube was heated using a nozzle-type resistivity heater equipped with a B-type thermocouple. The sample was then heated to $750^{\circ} \mathrm{C}$ at $10^{\circ} \mathrm{C} \mathrm{min}-1$ and regulated using an EUROTHERM regulator. The desorbed atomic or molecular species were ionized at $35 \mathrm{eV}$, mass separated in a $60^{\circ}$ magnetic separator, and the ion abundances measured with an electron multiplier. The desorbed molecules (atoms) were introduced directly into the ion source of the mass spectrometer under a high vacuum $\left(<10^{-5} \mathrm{~Pa}\right)$ without a carrier gas. The interactions of the desorbed species with the walls of the quartz cell were minimized, and any sudden changes in desorption were instantly registered without being smeared by the mixing effect due to the carrier gas. In addition, all desorbed species enter an almost closed ion source (resulting in a higher concentration of ions), which increases ionisation, and in turn enhances sensitivity.

For the majority of TPD measurements, a quadrupole mass spectrometer (QMS, Pfeiffer QMS 700) was employed as shown in scheme S1). The desorbed atoms or molecular species were ionized at $70 \mathrm{eV}$, mass separated in a quadrupole mass analyzer, and the ion abundances measured with an electron multiplier. The QMS's high dynamic range enables the measurement of ions with an abundance ratio of $10^{7}$, which is a definite advantage over the Nier-type instrument. Sample introduction into the ionization chamber was performed via a thick-walled quartz tube. The quartz tube was heated the same as in the NT-MS. The tube also serves to transfer the sample from the vacuum compartment to the ion source.

The declared sensitivity of the QMS is $10^{-6} \mathrm{~A} \mathrm{~Pa}^{-1}$, which is sufficient to measure samples containing $\mathrm{Hg}$ concentrations as low as $10 \mathrm{ng} \mathrm{g}^{-1}$. An additional benefit of using an MS as a detector is its ability to identify the various molecular species that evolve from the sample when heated.

Data analysis: All mass and TPD spectra (thermograms) were prepared using Origin 2017 software. Two different $\mathrm{Hg}$ isotopes, ${ }^{200} \mathrm{Hg}$ and ${ }^{202} \mathrm{Hg}$, were measured simultaneously. The data for the ${ }^{200} \mathrm{Hg}$ isotope was used to prepare the TPD spectra due to its lower background compared to ${ }^{202} \mathrm{Hg}$. Data obtained by QMS are interpreted by the Quadera software. The data is shown as a signal for the continuous measurement of $\mathrm{Hg}$ concentration in counts per second (CPS) on the ordinate axis versus temperature, ${ }^{\circ} \mathrm{C}$ on the absciss axis. In this way it is possible to observe the release of $\mathrm{Hg}$ with incremental increases in temperature. IVTANTHERMO Thermodynamic database and thermodynamic modelling software 3.0 was used to predict the thermodynamic data relating to the mass spectra.

\subsection{Description of experiments}

Experiments with $\mathrm{HgCl}_{2}$ : A known weight of ultra-pure $\mathrm{HgCl}_{2}(100 \mathrm{mg}$ ) was placed in the ion source of the NTMS. The cell was then cooled to $-15^{\circ} \mathrm{C}$ to prevent excessive sublimation during evacuation to a working pressure of $10^{-5} \mathrm{~Pa}$. The sample was then allowed to reach room temperature $\left(20^{\circ} \mathrm{C}\right)$.

Dry preparation of $\mathrm{Hg}$ compounds with $\mathrm{CaSO}_{4} \cdot 2 \mathrm{H}_{2} \mathrm{O}$ : Seven mercury compounds $\left(\mathrm{HgCl}_{2}, \mathrm{Hg}_{2} \mathrm{Cl}_{2}, \mathrm{HgO}\right.$ (yellow, Y), $\mathrm{HgO}\left(\mathrm{red}, \mathrm{R}\right.$ ), $\mathrm{HgS}, \mathrm{HgSO}_{4}$ and $\mathrm{Hg}_{2} \mathrm{SO}_{4}$ ) were mixed with $\mathrm{CaSO}_{4} \cdot 2 \mathrm{H}_{2} \mathrm{O}$. The preparation of the dry $\mathrm{Hg}$-standards is described in Sedlar et al. [30]. In short, $10 \mathrm{mg}$ of each pure $\mathrm{Hg}$ compound was added to $5 \mathrm{~g}$ of substrate powder $\mathrm{CaSO}_{4} \cdot 2 \mathrm{H}_{2} \mathrm{O}\left(1-2 \mathrm{mg} \mathrm{kg}^{-1}\right)$ in a zirconium container and mixed using a planetary mill (Fritsch planetary mill Pulverisette 7). 0.5-1 mg was taken for measurement.

Wet preparation of $\mathrm{Hg}$ compounds with $\mathrm{CaSO}_{4} \cdot 2 \mathrm{H}_{2} \mathrm{O}$ : Six different $\mathrm{Hg}$ compounds were selected $\left(\mathrm{HgCl}_{2}, \mathrm{Hg}_{2} \mathrm{Cl}_{2}\right.$, $\mathrm{HgO}, \mathrm{HgS}, \mathrm{HgSO}_{4}$ and $\mathrm{Hg}_{2} \mathrm{SO}_{4}$ ). Each solution was prepared separately by dissolving $1 \mathrm{mg}$ of the pure mercury compound in $1 \mathrm{~L}$ of a saturated solution of $\mathrm{CaSO}_{4} \cdot 2 \mathrm{H}_{2} \mathrm{O}$. An aliquot $(50 \mathrm{ml})$ was then left to dry to leave a precipitate of $\mathrm{Hg}$ compound $/ \mathrm{CaSO}_{4} \cdot 2 \mathrm{H}_{2} \mathrm{O}$. This was then analysed using TPD - MS. 
Wet preparation of $\mathrm{Hg}$ compounds with $\mathrm{FeOOH} /$ $\mathrm{CaSO}_{4} \cdot 2 \mathrm{H}_{2} \mathrm{O}$ : In a $100 \mathrm{ml}$ of each saturated solution of $\mathrm{CaSO}_{4} \cdot 2 \mathrm{H}_{2} \mathrm{O}$ with added $\mathrm{Hg}$-species: $\mathrm{HgS}, \mathrm{HgSO}_{4}, \mathrm{Hg}_{2} \mathrm{SO}_{4}$, $\mathrm{HgO}(\mathrm{Y}), \mathrm{HgCl}_{2}$ and $\mathrm{Hg}_{2} \mathrm{Cl}_{2}$ ), $0.5 \mathrm{~g}$ of $\mathrm{FeOOH}$ was added. The resulting brown solution containing non-soluble $\mathrm{FeOOH}$ was stirred, centrifuged and finally dried at $38{ }^{\circ} \mathrm{C}$. The mass of $\mathrm{FeOOH}$ added was calculated according to the amount of Fe and $\mathrm{Hg}$ present in original WFGD gypsum sample (ORIG-FF). From this $5 \mathrm{mg}$ was taken for TPD - MS analysis.

Dry preparation of $\mathrm{Hg}$ compounds with $\mathrm{FeOOH}$ : Four different mercury compounds were selected $\left(\mathrm{HgCl}_{2}\right.$, $\mathrm{Hg}_{2} \mathrm{Cl}_{2}, \mathrm{HgO}(\mathrm{Y})$ and $\mathrm{HgO}(\mathrm{R})$. About $1 \mathrm{mg}$ of each mercury compound was diluted with $5 \mathrm{mg}$ of $\mathrm{FeOOH}$ powder and mixed in a zirconium container using a planetary mill (Fritsch planetary mill Pulverisette 7). The mercury content was approximately $0.2 \mathrm{mg} \mathrm{g}^{-1}$.

Wet preparation of $\mathrm{Hg}$ compounds with $\mathrm{FeOOH}$ : Separately, $1 \mathrm{mg}$ of pure $\mathrm{HgO}(\mathrm{Y})$ and $\mathrm{HgCl}_{2}$ were added to the $\mathrm{FeOOH}$ solution $\left(0.5 \mathrm{~g} \mathrm{FeOOH}\right.$ in $100 \mathrm{~mL}^{-1}$ of distilled water). The mixture was stirred, centrifuged and then dried.

Addition of $\mathrm{NaCl}$ to a solution of $\mathrm{FeOOH} / \mathrm{CaSO}{ }_{4} \cdot 2 \mathrm{H}_{2} \mathrm{O}$ : To a solution of $\mathrm{HgCl}_{2}-\mathrm{CaSO}_{4} \cdot 2 \mathrm{H}_{2} \mathrm{O}$ was added $0.5 \mathrm{~g}$ of $\mathrm{FeOOH}$. A sufficient amount of $\mathrm{NaCl}$ was then added to give two different concentrations of $\mathrm{NaCl}$, namely, 0.006 and $0.17 \mathrm{M}$.

Ethical approval: The conducted research is not related to either human or animals use.

\section{Results and discussion}

The results are divided into four parts: 1) new findings regarding $\mathrm{HgCl}_{2}$ transformations during thermal heating, 2) physicochemical characterisation of the gypsum samples from Šoštanj TPP, 3) TPD spectra of $\mathrm{Hg}$ from the various gypsum size fractions of gypsum samples from Šoštanj TPP, and 4) a comparison of wet and dry methods for the preparation of mercury compounds for calibration purposes.

\subsection{Mass spectrometric characterization of $\mathrm{HgCl}_{2}$}

The presence of $\mathrm{HgCl}_{2}$ in the samples has been identified previously using either atmospheric pressure chemical ionization mass spectrometry, APCI-MS [37] or gas chromatography-mass spectrometer, GC-MS [38,39], but not as desorbed species in untreated solid samples using TPD method. Therefore, the possibility of direct identification of $\mathrm{HgCl}_{2}$ by MS was investigated.

In the ion source of the $\mathrm{MS}, \mathrm{HgCl}_{2}$ is ionized into $\mathrm{HgCl}_{2}{ }^{+}$, $\mathrm{HgCl}^{+}$and $\mathrm{Hg}^{+}$. According to NIST data [40], their relative abundances are 100:5:60, whereas from our previous work it is apparent that the mass spectrum (Figure S1) obtained from the desorption of $\mathrm{HgCl}_{2}$ from silica does not correspond to the NIST entry [30,40]. Wu et al. (2011), when studying the desorption of various $\mathrm{Hg}$ compounds from different matrices, found that $\mathrm{HgCl}_{2}$ predominately desorbs as atomic $\operatorname{Hg}(0)$, for which the authors could give no reasonable explanation given that $\mathrm{HgCl}_{2}$ is thermodynamically stable [41]. In the mass spectrometer, certain reactions govern the formation of $\mathrm{Hg}(0)$ during thermal desorption of $\mathrm{HgCl}_{2}$ at low pressures (vacuum $>10^{-5} \mathrm{~Pa}$ ) and in the presence of water hydrolysis of $\mathrm{HgCl}_{2}$ cannot be ruled out. To understand this better, additional experiments were performed using high purity $\mathrm{HgCl}_{2}$. Figure 1 shows the mass spectrum obtained. At $20^{\circ} \mathrm{C}$, the equilibrium pressure of the $\mathrm{HgCl}_{2}$ vapour over bulk $\mathrm{HgCl}_{2}$ was $5 \cdot 10^{-3} \mathrm{~Pa}$ (IVTANTHERMO database).

From Figure 1, it is apparent that the spectrum does not correspond to the NIST entry [40]. The excess of $\mathrm{Hg}^{+}$ ions most likely derives from elemental mercury, $\mathrm{Hg}(0)$, which is present as a contaminant in the $\mathrm{HgCl}_{2}$ reagent. The presence of $\mathrm{Hg}(0)$ as a contaminant in the pure reagent can be explained, in addition to possible hydrolysis, by the photodecomposition of $\mathrm{HgCl}_{2}$. To test this, the same measurement was repeated with a long-standing (old) $\mathrm{HgCl}_{2}$ reagent, revealing an even more profound deviation from the NIST data [40]. The deviation of the $\mathrm{HgCl}_{2}$ spectrum (Figure 1) from the NIST data was less intense than that seen in Figure S1. This was probably because of the use of a fresh ultra-purity $\mathrm{HgCl}_{2}$ reagent and a pressure of $5 \cdot 10^{-3} \mathrm{~Pa}$ [42].

The possible hydrolysis of $\mathrm{HgCl}_{2}$ within the MS has been investigated using thermochemical calculations in the IVTANTHERMO program incorporated into the Glusko database [42]. For this purpose, the $\mathrm{HgCl}_{2}: \mathrm{Hg}$ equilibrium ratio is computed as a function of total pressure, temperature and the $\mathrm{H}_{2} \mathrm{O}: \mathrm{HgCl}_{2}$ mole ratio (Figure 2). Analyses confirm that the hydrolysis of $\mathrm{HgCl}_{2}$ is promoted at low pressure, elevated temperatures and presence of water relative to $\mathrm{HgCl}_{2}$. Evidently, the $\mathrm{HgCl}_{2}: \mathrm{Hg}$ ratio in the vapour phase is temperature-pressure-concentration dependent.

Taking this into account, it becomes easy to explain the observations of Sedlar et al. [30], Uddin et al. [28] and $\mathrm{Wu}$ et al. [27], who studied the desorption of $\mathrm{HgCl}_{2}$ from various sorbents, such as $\mathrm{SiO}_{2}$ and $\mathrm{CaSO}_{4} \cdot 2 \mathrm{H}_{2} \mathrm{O}$, using MS. When the concentration of adsorbed $\mathrm{HgCl}_{2}$ is high, 


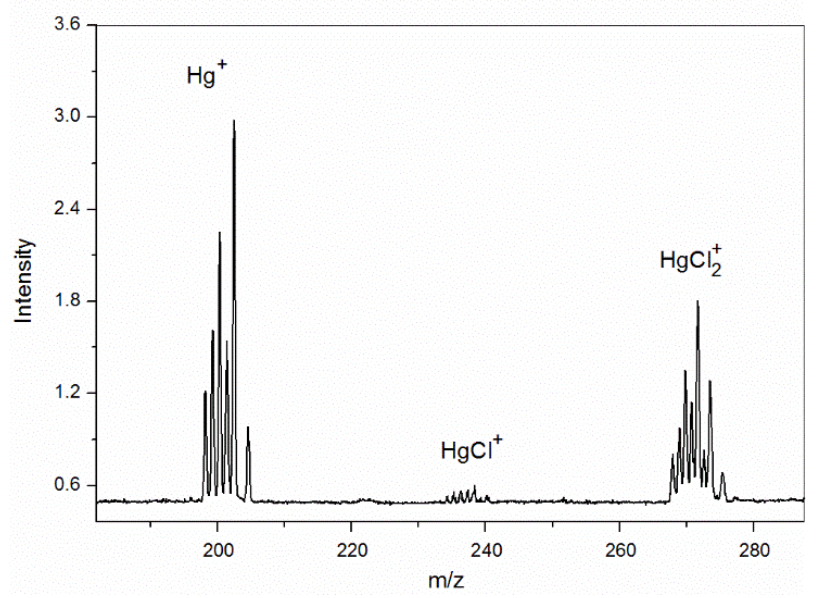

Figure 1: Mass spectra of $\mathrm{HgCl}_{2}$ vapours in equilibrium with condensed $\mathrm{HgCl}_{2}$ at $20^{\circ} \mathrm{C}$.
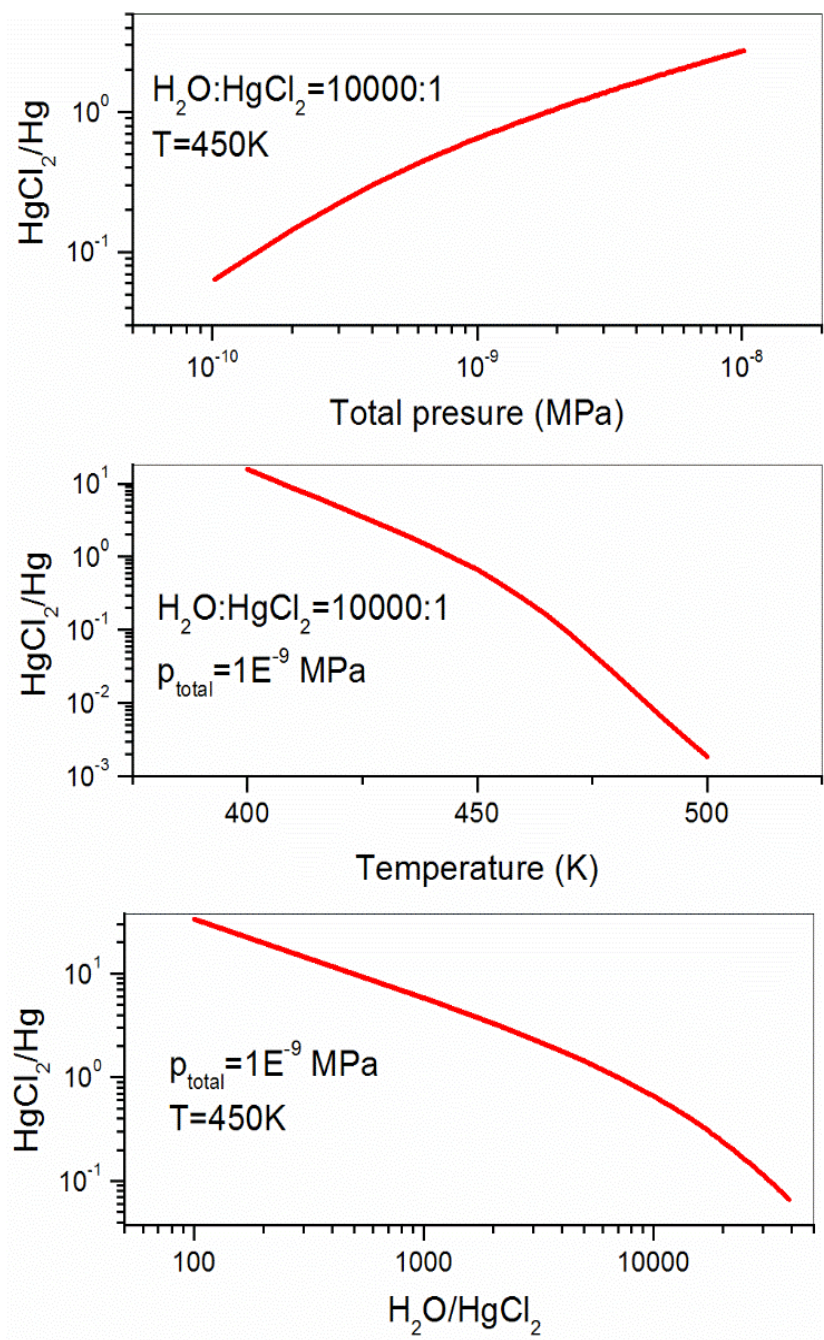

Figure 2: The calculated equilibrium ratio of $\mathrm{HgCl}_{2}: \mathrm{Hg}$ dependency on pressure, temperature and molar $\mathrm{H}_{2} \mathrm{O}: \mathrm{HgCl}_{2}$ vapour ratio. for example, when using pure $\mathrm{HgCl}_{2}$, it is reasonable to expect $\mathrm{HgCl}_{2}^{+}$ions in the mass spectrum, but in the presence of low amounts of $\mathrm{HgCl}_{2}$ relative to the amount of water, they decompose entirely into $\mathrm{Hg}(0)$. The concentration of mercury in the WFGD samples, similar to the bulk gypsum, was low $\left(<1 \mathrm{mg} \mathrm{kg}^{-1}\right)$ relative to the pure $\mathrm{Hg}$ compound, meaning that the presence of $\mathrm{HgCl}_{2}$ (by observing $\mathrm{HgCl}_{2}{ }^{+}$ions) using MS was unlikely, especially if the water was co-released. Gypsum also loses water when heated. Although, care should be taken when using thermodynamic calculations based on chemical equilibrium to explain kinetically governed processes, such as thermal desorption-decomposition, in the present case, the calculations agree with experimental observations $[27,28,30]$.

\subsection{Physico-chemical properties of the gypsum samples}

The results of the multi-elemental analysis (43 elements) of the fine and coarse fractions are given in Table S1. In the fine fraction, higher concentrations of most elements were favoured because of the smaller particle sizes, whereas Ca, $\mathrm{S}$ and $\mathrm{Sr}$ were the major elements in the coarse fractions, and their concentrations are typically lower in the fine fractions. In a previous study by Sedlar et al. (2015), halogens were at much higher concentrations in the fine gypsum fractions compared to the coarse fractions [13]. In this work, the enrichment of $\mathrm{Cl}$ and $\mathrm{Br}$ in fine fractions was not observed. Also in the finest fraction of RECY, the halogens are present at concentrations similar to those in the coarse fraction DISP-CF.

Figure $\mathrm{S} 2$ shows the Ca:S molar ratios of the different gypsum samples. The Ca:S ratio was nearly unit one in the coarse phases (ORIG-CF and DISP-CF), indicating pure $\mathrm{CaSO}_{4} \cdot 2 \mathrm{H}_{2} \mathrm{O}$, while in ORIG-FF and DISP-FF they were between 1 and 2. In RECY, there is a strong deviation from unit one, likely because of the presence of various carbonates. Moreover, Ca can precipitate with molecules and cluster ions other than $\mathrm{SO}_{4}{ }^{2-}[43]$.

Figure 3 shows the particle size distributions for all of the separated fractions. The coarse fractions have identical distributions (DISP-CF, ORIG-CF), while the three finer fractions (ORIG-FF, DISP-FF and RECY) differ from each other. In the case of RECY - the finest fraction, it contained the highest concentration of $\mathrm{Hg}$. The $\mathrm{Hg}$ concentrations in the coarse fractions were similar $\left(0.22-0.31 \mathrm{mg} \mathrm{kg}^{-1}\right)$, whereas the concentration of $\mathrm{Hg}$ in the finer fractions (Table S2) decreased as follows: RECY (20.6 mg kg-1) > 
DISP-FF (12.5 mg kg$)>$ ORIG-FF (8.94 $\left.\mathrm{mg} \mathrm{kg}^{-1}\right)$, which is consistent with the particle size distribution.

Figure S3 shows SEM images of various gypsum samples. In the bulk gypsum, coarse fractions prevail, and fine fractions are barely visible (Figure S3a). The coarse fractions (CF) are mostly composed of different $\mathrm{CaSO}_{4} \cdot 2 \mathrm{H}_{2} \mathrm{O}$ crystals, typically bigger than $>40 \mu \mathrm{m}$ size (Figure 3 and $\mathrm{S} 3 \mathrm{~b}$ ). In the fine fractions (Figure S3c), in addition to smaller $\mathrm{CaSO}_{4} \cdot 2 \mathrm{H}_{2} \mathrm{O}$ crystals, other solid by-products were formed under recirculation by precipitation and adsorption processes [43]. Inclusions of $\mathrm{Fe}$ and $\mathrm{Al}$ oxyhydroxides were present in the finer particles of the gypsum (Figures S3d and S4).

Figure S5 shows the TG-DTA thermograms of two gypsum samples, DISP-CF and RECY, recorded between $25^{\circ} \mathrm{C}$ and $550^{\circ} \mathrm{C}$. The mass loss of water in the case of DISP-CF (Figure S5a) matches closely the theoretical mass loss, which is additional proof that the CF fractions were 98\% pure gypsum, apart from RECY, which contained only 40\% gypsum (Figure S5b).

\subsection{Temperature programmed desorption (TPD) spectra of actual gypsum samples}

Figure 4 shows the TPD spectra of all six gypsum (ORIGFF, ORIG-CF, DISP-FF, DISP-CF, RECY, ORIG-bulk) samples obtained by QMS. A single peak appears in each sample with a peak maximum of $253-266^{\circ} \mathrm{C}$. The mixed fraction of ORIG gypsum (bulk) showed a medium-intensity peak because of the dilution of the fine fractions by the coarser ones; the latter represents the majority (by weight) of the WFGD material. The peak shapes and the positions on the temperature scale were similar in all fractions, suggesting a single decomposition process of a single $\mathrm{Hg}$ species. In addition, significantly lower $\mathrm{Hg}$ peaks were observed for both coarse fractions, DISP-CF and ORIG-CF consistent with the low Hg concentrations in those samples (Table S2).

\subsection{Temperature programmed desorption (TPD) spectra of dry and wet prepared mercury compounds}

To identify which of the mercury species decompose at $260^{\circ} \mathrm{C}$, spectra (Figure 4) were compared with seven dry mercury standards mixed with pure $\mathrm{CaSO}_{4} \cdot 2 \mathrm{H}_{2} \mathrm{O}$ (Figure 5; releasing temperatures are written in the Supplement Table S3).

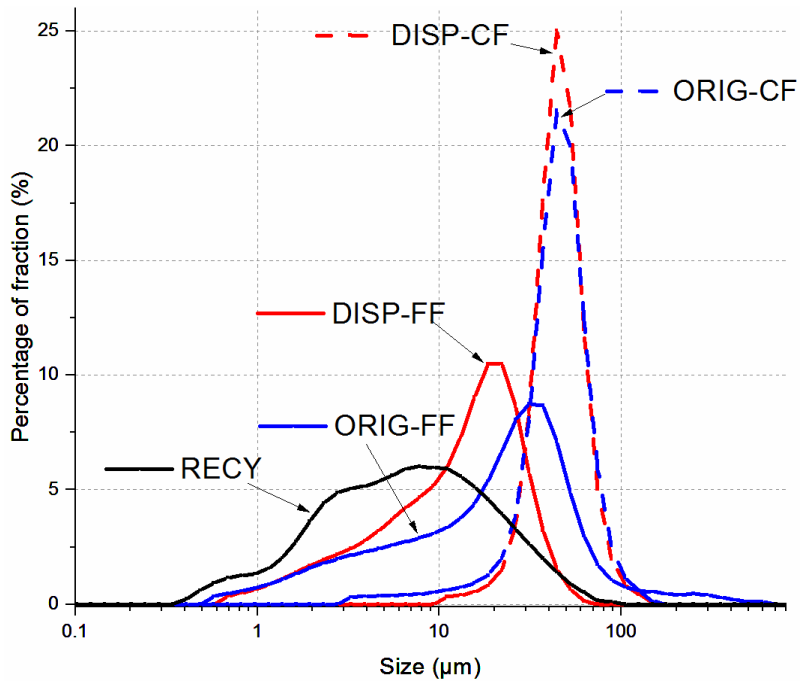

Figure 3: Distribution of particles in the finer and coarse fractions of gypsum.

None of the mixed samples (Figure 5) matched the actual gypsum samples (Figure 4). There are two possible reasons for this; i) none of the compounds is present in the gypsum or ii) the chemical composition of the gypsum changes the temperature of desorption of the Hg compounds. Another concern is that the system was "calibrated" using pure crystal mercury compounds mixed with crystalline $\mathrm{CaSO}_{4} \cdot 2 \mathrm{H}_{2} \mathrm{O}$, and does not reflect the conditions in the gypsum of the WFGD system. Therefore, a simple experiment was performed using mercury compounds dissolved in a saturated solution of $\mathrm{CaSO}_{4} \cdot 2 \mathrm{H}_{2} \mathrm{O}$. The solution was dried, and the TPD spectra for the remaining solid samples (solid precipitate) were recorded (Figure 6).

Inthesamplespreparedbydrymixing ofHgcompounds with $\mathrm{CaSO}_{4} \cdot 2 \mathrm{H}_{2} \mathrm{O}$, a desorption/decomposition process takes place from the surface of the crystals dispersed in the matrix $\left(\mathrm{CaSO}_{4} \cdot 2 \mathrm{H}_{2} \mathrm{O}\right)$, and diffusion is unlimited, meaning there is less interaction with the matrix. This produces narrower peaks at different positions on the temperature scale (Figure 5). In slurries, however, Hg exists in its ionic state and can form complexes or become attached to different particles. Therefore, it is unreasonable to expect identical decomposition spectra in both cases.

From the resulting TPD curves using $\mathrm{CaSO}_{4} \cdot 2 \mathrm{H}_{2} \mathrm{O}$ (Figure 6; Table S3), regardless of which $\mathrm{Hg}$ compound was used in the "wet" preparation of mercury compounds, all $\mathrm{Hg}$-species decomposed at a similar temperature (maximum at $243 \pm 13^{\circ} \mathrm{C}$ ), unlike in the case of dry mixing (Figure 5). The family of curves represents, therefore, the desorption/decomposition processes of $\mathrm{Hg}$ compounds 

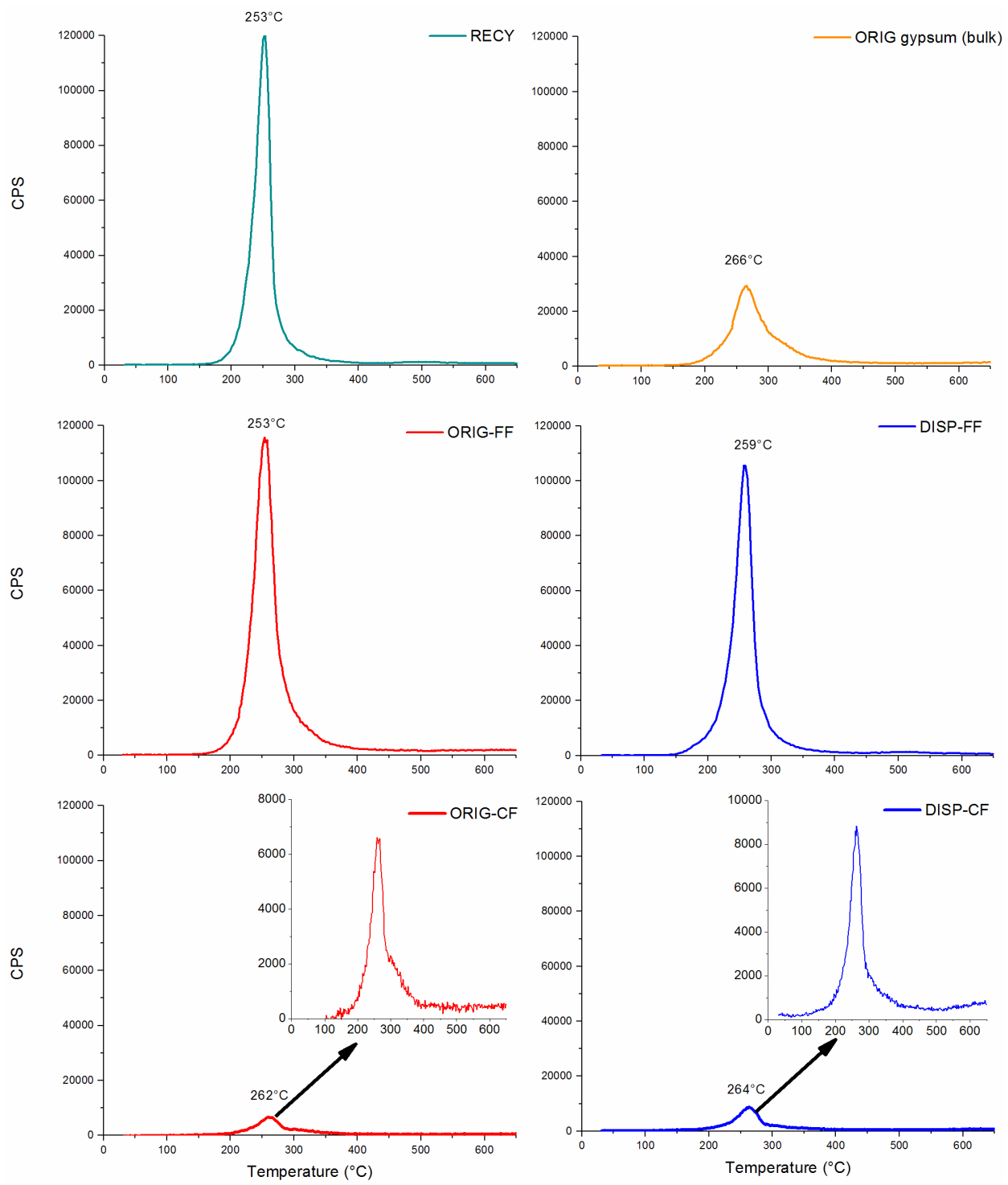

Figure 4: TPD spectra of five separated WFGD samples (fine and coarse fractions) and one mixed fraction containing both fractions (bulk gypsum).

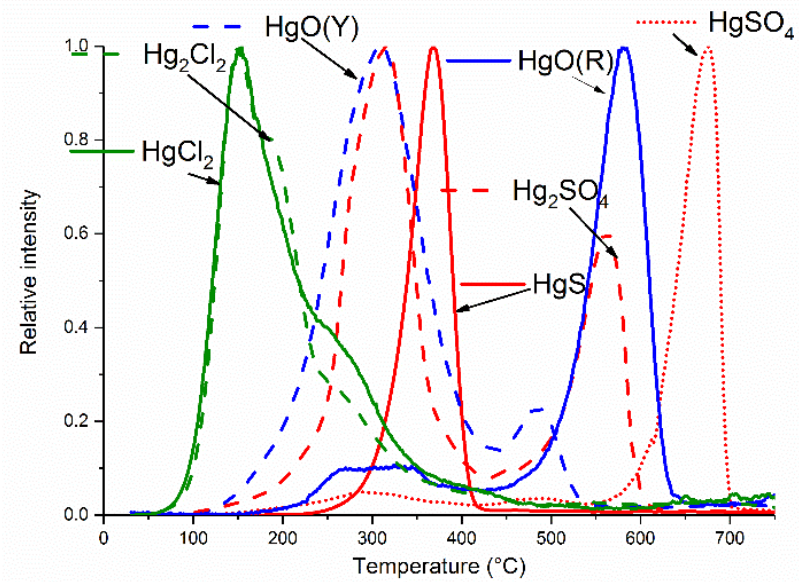

Figure 5: TPD spectra of mercury compounds prepared by dry mixing various $\mathrm{Hg}$-species with pure $\mathrm{CaSO}_{4} \cdot 2 \mathrm{H}_{2} \mathrm{O}$.

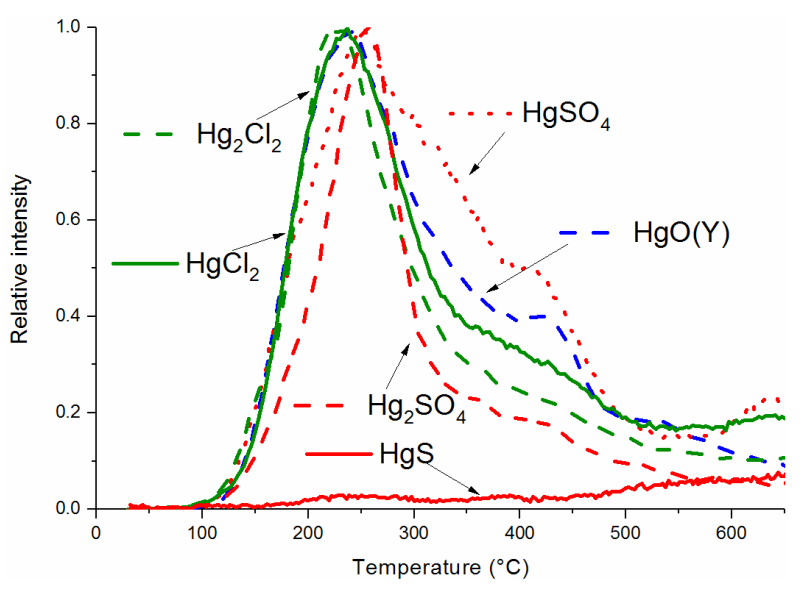

Figure 6: TPD spectra of mercury compounds in precipitates prepared by wet mixing various $\mathrm{Hg}$-compounds in a saturated solution of $\mathrm{CaSO}_{4} \cdot 2 \mathrm{H}_{2} \mathrm{O}$. Note: The absence of $\mathrm{HgS}$ peak is due to its low solubility. 
from the bulk of the $\mathrm{CaSO}_{4} \cdot 2 \mathrm{H}_{2} \mathrm{O}$ crystals. Evaporation processes are hindered by the diffusion of $\mathrm{Hg}$ through the crystal bulk and by the kinetics of the possible reactions taking place between the bulk $\mathrm{CaSO}_{4} \cdot 2 \mathrm{H}_{2} \mathrm{O}$ and $\mathrm{Hg}$ compounds during heating. The resulting TPD spectra all exhibit broad unsymmetrical peaks with humps, and the presence of several shoulders indicates various interactions between the $\mathrm{CaSO}_{4} \cdot 2 \mathrm{H}_{2} \mathrm{O}$ matrix and the $\mathrm{Hg}$ compounds.

The literature suggests that oxides and hydroxides (e.g., $\mathrm{Fe}, \mathrm{Al}$ and $\mathrm{Mn}$ ) may govern the adsorption processes of $\mathrm{Hg}$ compounds [5,6,10,11,20,44-48]. To verify the presence (effect) of Fe-species on Hg TDP spectra in solid samples, $\mathrm{FeOOH}$ was added. As seen in Figure 7, the obtained TPD spectra have narrower peak half-widths, with their maxima at $237 \pm 21^{\circ} \mathrm{C}$, similar to that in WFGD samples from Šoštanj TPP (Figure 4). The difference between the two sets of curves (Figures 6 and 7) is most visible regarding peak width and, to a lesser extent, peak positions. This indicates the influence of $\mathrm{FeOOH}$ on the $\mathrm{Hg}$ TPD spectra.

Figure 8a show TPD spectra of selected Hg-compounds after dry mixing with $\mathrm{FeOOH}$. The $\mathrm{Hg}$ compounds cover the matrix surface in the form of small crystals, and decomposition resembles that of the pure compound, where its thermal stability determines the position of the peak (Figure 8a), similar to dry $\mathrm{CaSO}_{4} \cdot 2 \mathrm{H}_{2} \mathrm{O}$ (Figure 5). Step decomposition of $\mathrm{Hg}_{2} \mathrm{Cl}_{2}$ into $\mathrm{HgCl}_{2}$ is seen in Figure 8a, whereas this is not observed in the case of $\mathrm{CaSO}_{4} \cdot 2 \mathrm{H}_{2} \mathrm{O}$. The decomposition profiles for both $\mathrm{HgO}$ mixed with $\mathrm{FeOOH}$ decompose at the same temperature compared to those mixed with $\mathrm{CaSO}_{4} \cdot 2 \mathrm{H}_{2} \mathrm{O}$. It follows that mercury compounds prepared using various dry substrates have different TPD spectra. The ability of different substrates to change the shape and the position of the TPD curves was confirmed in our previous study [30].

In another experiment, $\mathrm{HgCl}_{2}$ and $\mathrm{HgO}(\mathrm{Y})$ were mixed in a solution of $\mathrm{FeOOH}$ without the addition of $\mathrm{CaSO}_{4} \cdot 2 \mathrm{H}_{2} \mathrm{O}$ (Figure $8 \mathrm{~b}$ ). The TPD spectra of the precipitates prepared from chemically pure systems $\left(\mathrm{HgO}\right.$ or $\mathrm{HgCl}_{2}, \mathrm{FeOOH}$ and distilled $\mathrm{H}_{2} \mathrm{O}$ ) show an almost identical desorption/ decomposition profile suggesting the same $\mathrm{Hg}$-species are formed. Literature data propose the presence of $\mathrm{Hg}$ in the fine fractions with elevated concentrations of different elements such as iron $[2,3,20]$. Due to the similarities between the TPD spectra of actual WFGD samples from Šoštanj and the TPD spectra from the different experiments (Figures 4, 7 and $8 \mathrm{~b}$ ), the presence of Fe-species could influence the shape of the TPD spectra and the temperature at which Hg-species desorbed/decompose.

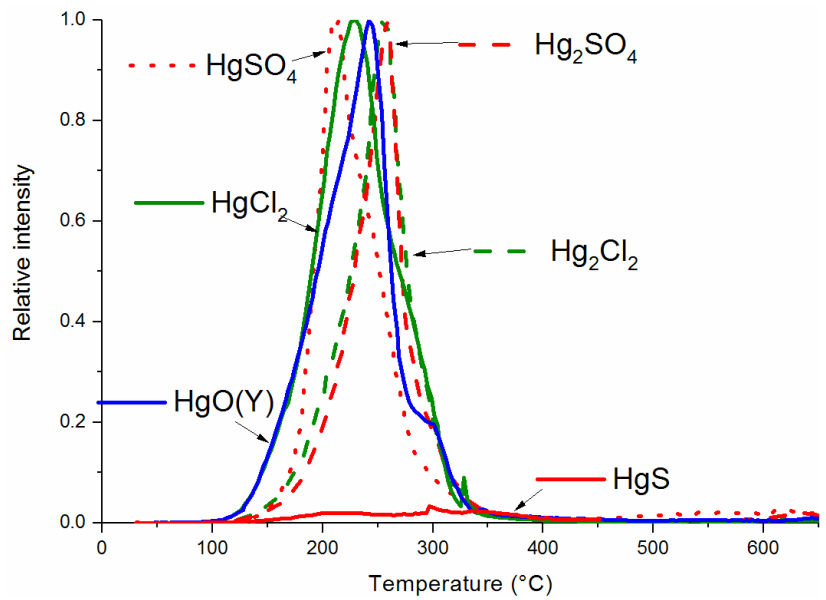

Figure 7: TPD spectra of mercury compounds in precipitate prepared by wet mixing various $\mathrm{Hg}$-species in a solution of $\mathrm{CaSO}_{4} \cdot 2 \mathrm{H}_{2} \mathrm{O}$ and $\mathrm{FeOOH}$. Note: The absence of HgS peak is due to its low solubility.
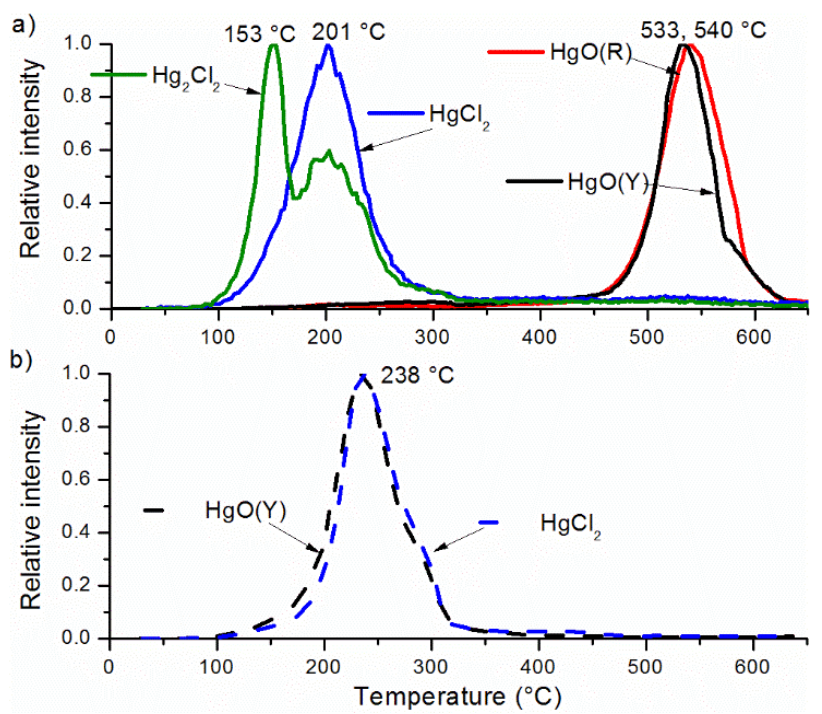

Figure 8: a) TPD spectra of $\mathrm{Hg}_{2} \mathrm{Cl}_{2}, \mathrm{HgCl}_{2}, \mathrm{HgO}(\mathrm{Y})$ and $\mathrm{HgO}(\mathrm{R})$ mixed with dry $\mathrm{FeOOH}$ and b) TPD spectra of $\mathrm{HgCl}_{2}$ and $\mathrm{HgO}(\mathrm{Y})$ in precipitates prepared by wet mixing of $\mathrm{Hg}$-species in a solution of $\mathrm{FeOOH}$.

Overall, in the WFGD gypsum slurry, different ions are present. The formation of $\mathrm{Hg}$ species is most likely attributed to the presence of $\mathrm{SO}_{3}{ }^{2-}, \mathrm{OH}^{-}$and $\mathrm{Cl}[6,8,9,49]$. At a pH of 6 (pH of WFGD is 5.4-5.6), the Hg species present in solution depend mainly on the presence of $\mathrm{Cl}^{-}$and $\mathrm{OH}$ ions. The literature shows the possibility of adsorption of $\mathrm{Cl}^{-}$and $\mathrm{Hg}$ to $\mathrm{FeOOH}$ as a prevailing process, but at a higher concentration of $\mathrm{Cl}$ ions, $\mathrm{Hg}$ adsorption is inhibited $[10,45,47]$. In the presence of chlorine ions at a lower $\mathrm{pH}$, $\mathrm{HgCl}_{2}$ forms instead of $\mathrm{Hg}(\mathrm{OH})_{2}$; while at a higher $\mathrm{pH}$, the formation of $\mathrm{Hg}(\mathrm{OH})_{2}$ is observed [44].

To evaluate the influence of chlorine on the TPD spectra of a solid precipitate prepared by dissolving 
$\mathrm{HgCl}_{2}$ in a saturated solution of $\mathrm{CaSO}_{4} \cdot 2 \mathrm{H}_{2} \mathrm{O} / \mathrm{FeOOH}$, two different experiments were performed: one with low (0.006 $\left.\mathrm{mol} \mathrm{L}^{-1}\right)$ and one with high $\left(0.17 \mathrm{~mol} \mathrm{~L}^{-1}\right)$ amounts of $\mathrm{Cl}$. The TPD spectra reveal an additional peak at the higher concentration of $\mathrm{Cl}^{-}$(Figure 9), while at the lower concentration, no change in the peak position or peak shape was observed, similar to the spectra with no addition of $\mathrm{NaCl}$. Low concentration of $\mathrm{Cl}^{-}$does not affect the TPD spectra whereas at higher $\mathrm{NaCl}$ levels more stable Hg compound form, which is shown by the existence of a peak at higher temperatures. However, the hydrolytic effect and specific experimental conditions, means that mass spectrometry cannot confirm the presence of $\mathrm{HgCl}_{2}$ molecules from observing $\mathrm{HgCl}_{2}^{+}$ions.

Mercury sulphide is commonly considered the most likely $\mathrm{Hg}$ species present in WFGD samples [1,15]. Its formation is thought to occur at higher loads of sulphur due to the disproportionation of $\mathrm{SO}_{3}{ }^{2 \cdot}$ into $\mathrm{S}^{2 \cdot}$ and $\mathrm{SO}_{4}{ }^{2 \cdot}[17]$. The solubility product of $\mathrm{HgS}$ is extremely low $\left(\mathrm{K}_{\mathrm{sp}}=2 \cdot 10^{-53}\right)$ $[50,51]$, meaning that it should precipitate in the slurry. In the Šoštanj TPP samples, this is not the case because its decomposition temperature (Figure 5: HgS TPD spectrum obtained by dry preparation) is about $100^{\circ} \mathrm{C}$ higher than the measured WFGD gypsum samples (Figure 4). To prove this, Šoštanj TPP sample (ORIG-FF) were blended with pure solid HgS prepared by dry mixing (Figure 10a). In the spectra an additional peak appears as a consequence of $\mathrm{HgS}$ decomposition meaning that the original WFGD sample does not contain $\mathrm{HgS}$.

Similar experiments were repeated using $\mathrm{Hg}$ compounds prepared in a saturated solution of $\mathrm{CaSO}_{4} \cdot 2 \mathrm{H}_{2} \mathrm{O}$ with added $\mathrm{FeOOH}$. Additional peaks appear (Figure 10b) at similar temperatures than in the actual gypsum slurry (ORIG-FF). Although many authors identify HgS in their samples [12,15-18], it was not possible to prove its presence in the gypsum samples in this study since no characteristic TPD peak was observed between 300 and $400^{\circ} \mathrm{C}$. Here are reasons why it could not be detected: i) $\mathrm{HgS}$ is not present in the gypsum samples, ii) the presence of $\mathrm{HgS}$ is too low to be detected by the TPD, and the peak for HgS is hidden in the background, iii) $\mathrm{HgS}$ could be present in the form of metacinnabar which is released at lower temperatures according to the publications of other researchers and has not been tested in the present work, and iv) HgS could be present as $\mathrm{Hg}$-S bonded to the substrate such as Fe or other adsorptive compounds, where the strength of the bonds are weaker than in the crystalline phase. It follows that decomposition at lower temperatures than with crystalline $\mathrm{HgS}$ is possible. Further studies are needed to confirm the presence of $\mathrm{HgS}$ in actual gypsum samples.

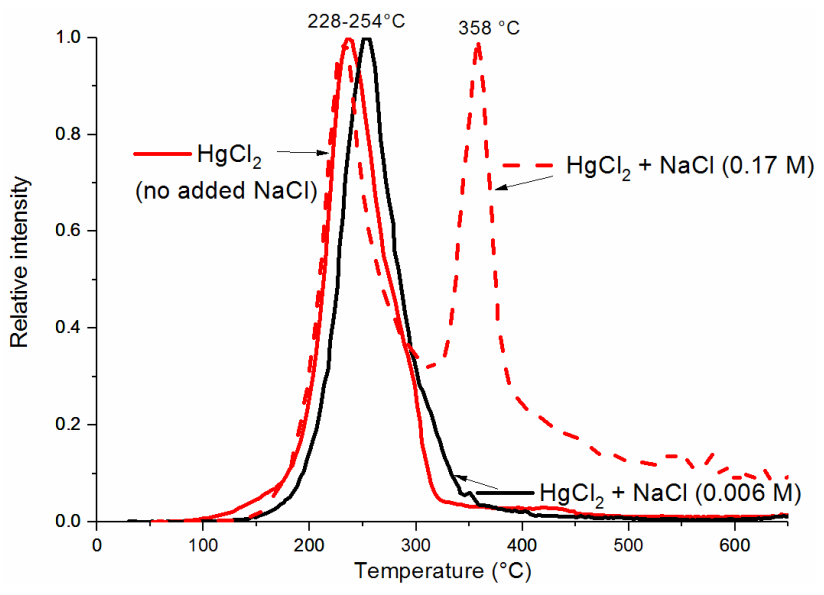

Figure 9: TPD spectra of precipitate of $\mathrm{HgCl}_{2}$ in a saturated solution of $\mathrm{CaSO}_{4} \cdot 2 \mathrm{H}_{2} \mathrm{O}$ and $\mathrm{FeOOH}$ without the addition $\mathrm{NaCl}$ and with two different concentrations of $\mathrm{NaCl}(0.006$ and $0.17 \mathrm{M})$.

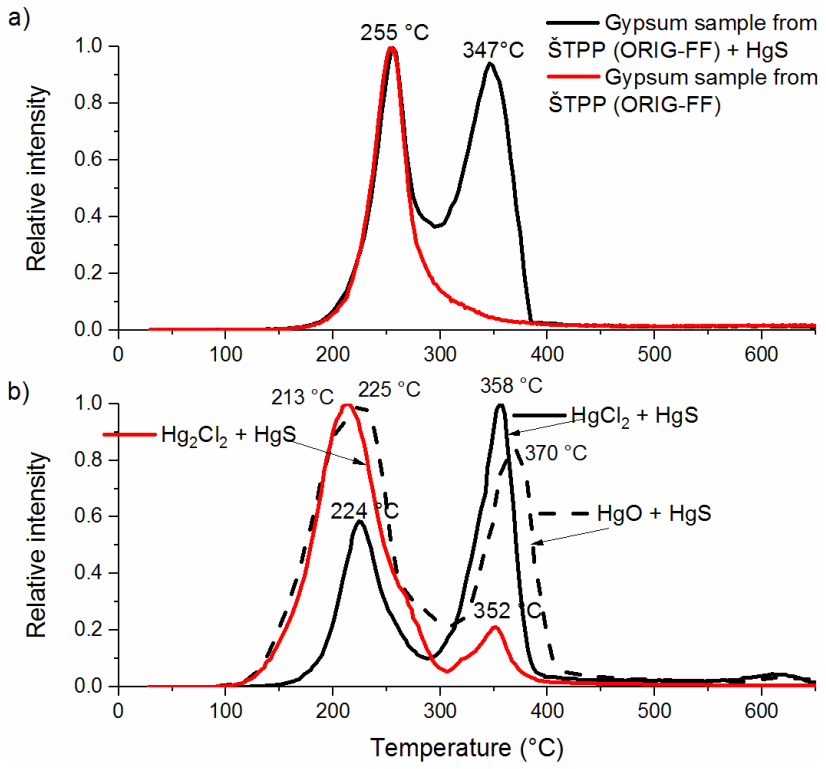

Figure 10: TPD spectra of a) ORIG-FF with and without $\mathrm{HgS}$ addition and $b$ ) various wet-prepared $\mathrm{Hg}$ standards mixed with the dryprepared $\mathrm{HgS}$ standard.

\section{Conclusions}

The use of a mass spectrometer, as a detector for studying desorption/decomposition processes of $\mathrm{Hg}$ compounds from WFGD samples, proved to be a good choice. For example, the observation of decomposition fragments of volatile species evolved during decomposition, and by means of a mass spectrometer with a high sensitivity, it was possible to measure samples with $\mathrm{Hg}$ contents $>10 \mathrm{ng} \mathrm{g}^{-1}$. The background level of ions with a mass number around $\mathrm{m} / \mathrm{z} 200$ governs the limits of detection and not electronic sensitivity. The drawback of using 
an MS is the high background levels as a result of other substances evaporating from the sample along with mercury. Regarding $\mathrm{HgCl}_{2}$, hydrolysis prevented the direct identification of $\mathrm{HgCl}_{2}^{+}$ions in the mass spectrum that would otherwise have confirmed the presence of $\mathrm{HgCl}_{2}$ in the WFGD samples. Furthermore, the possibility of hydrolysis was confirmed theoretically. Because of the low $\mathrm{Cl}^{-}$concentrations in all gypsum fractions, the presence of $\mathrm{Hg}$ - $\mathrm{Cl}$ species is rather unlikely but is not excluded.

The TPD spectra of the Šoštanj TPP samples indicate a single, well-defined peak, which could not be reproduced using mercury standards prepared by the dry mixing of the substrate with $\mathrm{Hg}$ compounds. For comparison, "wetprepared" mercury compounds were used for the first time. Experimental work was mainly devoted to the study of desorption/decomposition of different $\mathrm{Hg}$-species mixed in a solution of $\mathrm{FeOOH}$ and $\mathrm{CaSO}_{4} \cdot 2 \mathrm{H}_{2} \mathrm{O}$. The TPD curves of solid precipitates showed only a single peak similar in shape and position to the Šoštanj TPP gypsum samples. More comprehensive studies are needed to characterize the $\mathrm{Hg}$ compounds formed at the surface of different dried solid residues as well as in the actual gypsum samples. Finally, further experimental work is needed to confirm the presence of $\mathrm{Hg}-\mathrm{S}, \mathrm{Hg}-\mathrm{Cl}$ and other $\mathrm{Hg}$ compounds.

Acknowledgment: This work was funded by the Slovenian Research Agency (ARRS) program P1-0143 and the Young researcher's program PR-05031. The study was also supported by the EMPIR MercOx project (16ENV01). We thank the Šoštanj thermal power plant for permitting us to obtain the samples and Peter Frkal for sampling. We would like to thank the The Centre for Electron Microscopy and Microanalysis (CEMM) for SEM and EDS analysis and the Department of Electronic Ceramics for their help in performing the TG/DTA analysis.

Conflict of interest: Authors state no conflict of interest.

Supplementary Data: The following are Supplementary data to this article.

\section{References}

[1] Liu X., Wang S., Zhang L, Wu Y., Duan L., Hao J., Speciation of mercury in FGD gypsum and mercury emission during the wallboard production in China, Fuel, 2013, 111, 621-7. doi:http://dx.doi.org/10.1016/j.fuel.2013.03.052.

[2] Beatty W.L., Schroeder K., Beatty C.L.K., Mineralogical Associations of Mercury in FGD Products, Energy \& Fuels, 2012, 26, 3399-406. doi:10.1021/ef300033u.
[3] Kairies C.L., Schroeder K.T., Cardone C.R., Mercury in gypsum produced from flue gas desulfurization, Fuel, 2006, 85, 2530-6. doi:http://dx.doi.org/10.1016/j.fuel.2006.04.027.

[4] Shuetze J., Kunth D., Weissbach S., Koeser H., Mercury Vapor Pressure of Flue Gas Desulfurization Scrubber Suspensions: Effects of pH Level, Gypsum, and Iron, Environ. Sci. Technol., 2012, 46, 3008-13.

[5] Stergaršek A., Horvat M.., Frkal P., Stergaršek J., Removal of $\mathrm{Hg}^{0}$ from flue gases in wet FGD by catalytic oxidation with air - An experimental study, Fuel, 2010, 89, 3167-77. doi:10.1016/j. fuel.2010.04.006.

[6] Stergaršek A., Horvat M., Frkal P., Ribeiro Guevara S., Kocjančič R., Removal of $\mathrm{Hg}^{\circ}$ in wet FGD by catalytic oxidation with air - A contribution to the development of a process chemical model, Fuel, 2013, 107, 183-91. doi:10.1016/j.fuel.2012.08.001.

[7] Córdoba P., Font O., Izquierdo M., Querol X., Tobías A., LópezAntón M.A., et al., Enrichment of inorganic trace pollutants in re-circulated water streams from a wet limestone flue gas desulphurisation system in two coal power plants, Fuel Process. Technol., 2011, 92, 1764-75. doi:http://dx.doi. org/10.1016/j.fuproc.2011.04.025.

[8] Heidel B., Rogge T., Scheffknecht G., Controlled desorption of mercury in wet FGD waste water treatment, Appl. Energy, 2016, 162, 1211-7. doi:http://dx.doi.org/10.1016/j. apenergy.2015.05.016.

[9] Ochoa-González R., Díaz-Somoano M., Rosa Martínez-Tarazona $\mathrm{M}$, . Control of $\mathrm{Hg}^{0}$ re-emission from gypsum slurries by means of additives in typical wet scrubber conditions, Fuel, 2013, 105, 112-8. doi:http://dx.doi.org/10.1016/j.fuel.2012.05.044.

[10] Kim C.S., Rytuba J.J., Brown G.E., EXAFS study of mercury(II) sorption to Fe- and Al-(hydr)oxides: II. Effects of chloride and sulfate, J. Colloid. Interface Sci., 2004, 270, 9-20. doi:http:// dx.doi.org/10.1016/j.jcis.2003.07.029.

[11] Kim C.S., Rytuba J.J., Brown G.E., EXAFS study of mercury(II) sorption to Fe- and Al-(hydr)oxides: I. Effects of pH, J. Colloid. Interface Sci., 2004, 271, 1-15. doi:http://dx.doi.org/10.1016/ S0021-9797(03)00330-8.

[12] Milobowski M.G., Amrhein G.T., Kudlac G.A., Yurchhison D.M., Wet FGD Enhanced Mercury Control for Coal-Fired Utility Boilers, Proc. US EPA/DOE/EPRI Comb. Power Plant Air. Pollut. Control Symp. Mega Symp., Chicago, 20-23. August: 2001.

[13] Sedlar M., Pavlin M., Jaćimović R., Stergaršek A., Frkal P., Horvat M., Temperature Fractionation (TF) of Hg Compounds in Gypsum from Wet Flue Gas Desulfurization System of the Coal Fired Thermal Power Plant ( TPP), Am. J. Anal. Chem., 2015, 6, 1, 939-56.

[14] Zou R., Zeng X., Luo G., Qiu Y., Zhang B., Xu Y., et al. Mercury stability of byproducts from wet flue gas desulfurization devices, Fuel, 2016, 186, 215-21. doi:http://dx.doi. org/10.1016/j.fuel.2016.08.023.

[15] Zhu Z., Zhuo Y., Fan Y., Wang Z., Fate of mercury in flue gas desulfurization gypsum determined by Temperature Programmed Decomposition and Sequential Chemical Extraction., J. Environ. Sci., 2016, 43, 169-76. doi:http:// dx.doi.org/10.1016/j.jes.2015.09.011.

[16] Rallo M., Lopez-Anton M.A., Perry R., Maroto-Valer M.M., Mercury speciation in gypsums produced from flue gas desulfurization by temperature programmed decomposition, Fuel, 2010, 89, 2157-9. doi:http://dx.doi.org/10.1016/j. fuel.2010.03.037. 
[17] Sui Z., Zhang Y., Li W., Orndorff W., Cao Y., Pan W.-P., Partitioning effect of mercury content and speciation in gypsum slurry as a function of time, J. Therm. Anal. Calorim., 2015, 119, 1611-8. doi:10.1007/s10973-015-4403-9.

[18] Lee J.-Y., Cho K., Cheng L., Keener T.C., Jegadeesan G., Al-Abed S.R., Investigation of a Mercury Speciation Technique for Flue Gas Desulfurization Materials, J. Air Waste Manage. Assoc., 2009, 59, 972-9. doi:10.3155/1047-3289.59.8.972.

[19] Córdoba P., Maroto-Valer M., Ayora C., Perry R., Rallo M., Font O., et al. Unusual Speciation and Retention of $\mathrm{Hg}$ at a CoalFired Power Plant, Environ. Sci. Technol., 2012, 46, 7890-7. doi:10.1021/es301106x.

[20] Al-Abed S.R., Jegadeesan G., Scheckel K.G., Tolaymat T. Speciation, Characterization, and Mobility of As, Se, and $\mathrm{Hg}$ in Flue Gas Desulphurization Residues, Environ. Sci. Technol., 2008, 42, 1693-8. doi:10.1021/es702479n.

[21] Sun M., Hou J., Cheng G., Baig S.A., Tan L., Xu X., The relationship between speciation and release ability of mercury in flue gas desulfurization (FGD) gypsum, Fuel, 2014, 125, 66-72. doi:http://dx.doi.org/10.1016/j.fuel.2014.02.012.

[22] Hao Y., Wu S., Pan Y., Li Q., Zhou J., Xu Y., et al. Characterization and leaching toxicities of mercury in flue gas desulfurization gypsum from coal-fired power plants in China, Fuel, 2016. doi:10.1016/j.fuel.2016.02.091.

[23] Raposo C., Windmöller C.C., Durão Júnior W.A., Mercury speciation in fluorescent lamps by thermal release analysis, Waste Manag., 2003, 23, 879-86. doi:http://dx.doi. org/10.1016/S0956-053X(03)00089-8.

[24] Windmöller C.C., Wilken R.-D., Jardim W.D.F., Mercury speciation in contaminated soils by thermal release analysis. Water Air Soil Pollut., 1996, 89, 399-416. doi:10.1007/ BF00171644.

[25] Biester H., Scholz C., Determination of Mercury Binding Forms in Contaminated Soils: Mercury Pyrolysis versus Sequential Extractions, Environ. Sci. Technol., 1997, 31, 233-9. doi:10.1021/es960369h.

[26] Lopez-Anton M.A., Yuan Y., Perry R., Maroto-Valer M.M., Analysis of mercury species present during coal combustion by thermal desorption, Fuel, 2010, 89, 629-34. doi:http://dx.doi. org/10.1016/j.fuel.2009.08.034.

[27] Wu S., Uddin M.A., Nagano S., Ozaki M., Sasaoka E., Fundamental Study on Decomposition Characteristics of Mercury Compounds over Solid Powder by TemperatureProgrammed Decomposition Desorption Mass Spectrometry, Energy \& Fuels, 2011, 25, 144-53. doi:10.1021/ef1009499.

[28] Uddin M.A., Ozaki M., Sasaoka E., Wu S., TemperatureProgrammed Decomposition Desorption of Mercury Species over Activated Carbon Sorbents for Mercury Removal from Coal-Derived Fuel Gas, Energy \& Fuels, 2009, 23, 4710-6. doi:10.1021/ef801068z.

[29] Ozaki M., Uddin M.A., Sasaoka E., Wu S., Temperature programmed decomposition desorption of the mercury species over spent iron-based sorbents for mercury removal from coal derived fuel gas, Fuel, 2008, 87, 3610-5. doi:http://dx.doi. org/10.1016/j.fuel.2008.06.011.

[30] Sedlar M., Pavlin M., Popovič A., Horvat M., Temperature stability of mercury compounds in solid substrates, Open Chem., 2015, 13, 404-19. doi:10.1515/chem-2015-0051.

[31] Kubaschewski O., Alcock C.B., Evans A.L., Oxford, Pergamon, 1967.
[32] Luo G., Yao H., Xu M., Gupta R., Xu Z., Identifying modes of occurrence of mercury in coal by temperature programmed pyrolysis, Proc. Combust. Inst., 2011, 33, 2763-9. doi:http:// dx.doi.org/10.1016/j.proci.2010.06.108.

[33] Shuvaeva O.V., Gustaytis M.A., Anoshin G.N., Mercury speciation in environmental solid samples using thermal release technique with atomic absorption detection, Anal. Chim. Acta, 2008, 621, 148-54. doi:http://dx.doi. org/10.1016/j.aca.2008.05.034.

[34] Stergaršek A., Horvat M., Kotnik J., Tratnik J., Frkal P., Kocman D., et al. The role of flue gas desulphurisation in mercury speciation and distribution in a lignite burning power plant, Fuel, 2008, 87, 3504-12. doi:10.1016/j.fuel.2008.06.003.

[35] Knudsen M., Die maximale Verdampfungsgeschwindigkeit des Quecksilbers, Ann. Phys., 1915, 352, 697-708. doi:10.1002/ andp.19153521306.

[36] Popovič A., Mass spectrometric determination of the ionisation cross-sections of $\mathrm{BaO}, \mathrm{Ba}, \mathrm{BaF}_{2}$ and $\mathrm{Bal}_{2}$ by electron impact, Int. J. Mass Spectrom., 2003, 230, 99-112. doi:http://dx.doi. org/10.1016/j.ijms.2003.07.002.

[37] Deeds D.A., Ghoshdastidar A., Raofie F., Guérette É.-A., Tessier A., Ariya P.A., Development of a Particle-Trap PreconcentrationSoft Ionization Mass Spectrometric Technique for the Quantification of Mercury Halides in Air, Anal. Chem., 2015, 87, 5109-16. doi:10.1021/ac504545w.

[38] Jones C.P., Lyman S.N., Jaffe D.A., Allen T., O’Neil T.L., Detection and quantification of gas-phase oxidized mercury compounds by GC/MS, Atmos. Meas. Tech., 2016, 9, 2195-205. doi:10.5194/amt-9-2195-2016.

[39] Babko S.V., Monttgomery J.L., Battleson D.M., Whitworth C.G., Sears J., Summer J., et al, Mercury speciation analysis by gas chromatography/electron impact/mass spectrometry, Waste Manag., Tucson, AZ, USA: 2001.

[40] NIST Chemistry WebBook, Mass spectrum of $\mathrm{HgCl}_{2}$ (electron ionization) 2014. http://webbook.nist.gov/cgi/cbook.cgi?S pec $=C 7487947 \&$ Index $=0$ \&Type $=$ Mass $\&$ Large $=0 n \& S V G=0 n$ (accessed November 9, 2016).

[41] Kozin L.F., Hansen S.C., Mercury Handbook, The Royal Society of Chemistry, 2013. doi:10.1039/9781849735155.

[42] Iorish V.S., Belov G.V., Gurvich L.V., IVTANTHERMO database 2005.

[43] Córdoba P., Castro I., Maroto-Valer M., Querol X., The potential leaching and mobilization of trace elements from FGDgypsum of a coal-fired power plant under water re-circulation conditions, J. Environ Sci., 2015, 32, 72-80. doi:10.1016/j. jes.2014.11.009.

[44] Inoue Y., Munemori M., Coprecipitation of mercury(II) with iron(III) hydroxide, Environ. Sci. Technol., 1979, 13, 443-5. doi:10.1021/es60152a001.

[45] Tiffreau C., Lützenkirchen J., Behra P., Modeling the Adsorption of Mercury(II) on (Hydr)oxides, J Colloid. Interface Sci., 1995, 172, 82-93. doi:http://dx.doi.org/10.1006/jcis.1995.1228.

[46] Lockwood R.A., Chen K.Y., Adsorption of Hg(II) by hydrous manganese oxides, Environ. Sci. Technol., 1973, 7, 1028-34.

[47] Bonnissel-Gissinger P., Alnot M., Lickes J.-P., Ehrhardt J.-J., Behra P., Modeling the Adsorption of Mercury(II) on (Hydr) oxides II: $\alpha$-FeOOH (Goethite) and Amorphous Silica, J. Colloid. Interface Sci., 1999, 215, 313-22. doi:http://dx.doi. org/10.1006/jcis.1999.6263. 
[48] Gunneriusson L., Sjöberg S., Surface Complexation in the $\mathrm{H}+-$ Goethite $(\alpha-\mathrm{FeOOH})-\mathrm{Hg}(\mathrm{II})-\mathrm{Chloride}$ System, J. Colloid. Interface Sci., 1993, 156, 121-8. doi:https://doi.org/10.1006/ jcis.1993.1090.

[49] Sun M., Cheng G., Lu R., Tang T., Baig S.A., Xu X., Characterization of $\mathrm{Hg}^{0}$ re-emission and $\mathrm{Hg}^{2+}$ leaching potential from flue gas desulfurization (FGD) gypsum, Fuel Process. Technol., 2014, 118, 28-33. doi:http://dx.doi.org/10.1016/j. fuproc.2013.08.002.

[50] Hepler L.G., Olofsson G., Mercury: Thermodynamic Properties, Chemical Equilibria, and Standard Potentials, Chem. Rev., 1975, 75, 585-602.

[51] Wagman D.D., Evans W.H., Parker V.B., Haiow I., Bailey S.M., Schumm R.H., Selected Values of Chemical Thermodynamic Properties, U.S. Government Printing Office, Washington, D.C., 1968.

Supplemental Material: The online version of this article offers supplementary material (https://doi.org/10.1515/chem-2018-0046). 